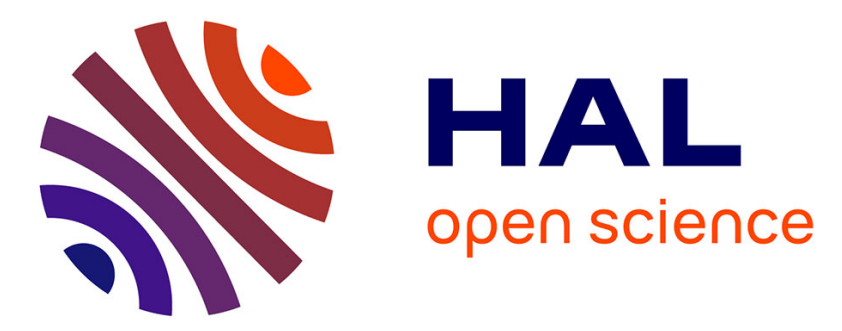

\title{
Effects of chronic morphine and morphine withdrawal on gene expression in rat peripheral blood mononuclear cells.
}

\author{
Stephane Desjardins, Emilie Belkai, Dominique Crete, Laurie Cordonnier, \\ Jean-Michel Scherrmann, Florence Noble, Cynthia Marie-Claire
}

\section{To cite this version:}

Stephane Desjardins, Emilie Belkai, Dominique Crete, Laurie Cordonnier, Jean-Michel Scherrmann, et al.. Effects of chronic morphine and morphine withdrawal on gene expression in rat peripheral blood mononuclear cells.. Neuropharmacology, 2008, 55 (8), pp.1347-54. 10.1016/j.neuropharm.2008.08.027 . inserm-00343477

\section{HAL Id: inserm-00343477 https://www.hal.inserm.fr/inserm-00343477}

Submitted on 1 Dec 2008

HAL is a multi-disciplinary open access archive for the deposit and dissemination of scientific research documents, whether they are published or not. The documents may come from teaching and research institutions in France or abroad, or from public or private research centers.
L'archive ouverte pluridisciplinaire HAL, est destinée au dépôt et à la diffusion de documents scientifiques de niveau recherche, publiés ou non, émanant des établissements d'enseignement et de recherche français ou étrangers, des laboratoires publics ou privés. 


\title{
Effects of chronic morphine and morphine withdrawal on gene expression in rat peripheral blood mononuclear cells
}

Desjardins Stephane, Belkai Emilie, Crete Dominique, Cordonnier Laurie, Scherrmann Jean-Michel , Noble Florence * Marie-Claire Cynthia

NAVVEC, Neuropsychopharmacologie des addictions. Vulnérabilité et variabilité expérimentale et clinique CNRS : UMR7157, INSERM : U705, IFR71, Université Paris Descartes - Paris V, Université Denis Diderot - Paris VII, FR

* Correspondence should be adressed to: Florence Noble <florence.noble@parisdescartes.fr>

\begin{abstract}
Summary

Chronic morphine treatment alters gene expression in brain structures. There are increasing evidences showing a correlation, in gene expression modulation, between blood cells and brain in psychological troubles. To test whether gene expression regulation in blood cells could be found in drug addiction, we investigated gene expression profiles in peripheral blood mononuclear (PBMC) cells of saline and morphine-treated rats. In rats chronically treated with morphine, the behavioural signs of spontaneous withdrawal were observed and a withdrawal score was determined. This score enabled to select the time points at which the animals displayed the mildest and strongest withdrawal signs (12h and 36h after the last injection). Oligonucleotide arrays were used to assess differential gene expression in the PBMCs and quantitative real-time RT-PCR to validate the modulation of several candidate genes $12 \mathrm{~h}$ and $36 \mathrm{~h}$ after the last injection. Among the 812 differentially expressed candidates, several genes (Adcy5, Htr2a) and pathways (Map kinases, G-proteins, integrins) have already been described as modulated in the brain of morphine-treated rats. Sixteen out of the twenty four tested candidates were validated at $12 \mathrm{~h}$, some of them showed a sustained modulation at $36 \mathrm{~h}$ while for most of them the modulation evolved as the withdrawal score increased. This study suggests similarities between the gene expression profile in PBMCs and brain of morphine treated rats. Thus, the searching of correlations between the severity of the withdrawal and the PBMCs gene expression pattern by transcriptional analysis of blood cells could be promising for the study of the mechanisms of addiction.
\end{abstract}

MESH Keywords Analysis of Variance ; Animals ; Behavior, Animal ; drug effects ; Gene Expression Profiling ; Gene Expression Regulation ; drug effects ; Leukocytes, Mononuclear ; drug effects ; metabolism ; Male ; Morphine ; administration \& dosage ; pharmacology ; Narcotics ; administration \& dosage ; pharmacology ; Oligonucleotide Array Sequence Analysis ; RNA, Messenger ; genetics ; metabolism ; Rats ; Rats, Sprague-Dawley ; Substance Withdrawal Syndrome ; genetics ; metabolism ; Time Factors

\section{Introduction}

Opiates are among the most largely used addictive drugs. Abused opiates primarily interact with $\mu$ opioid receptors in the central nervous system and induce long-term behavioral and cellular alterations. A current challenge in opiate addiction is to understand the molecular alterations underlying the adaptative changes observed. The structure of different classes of opioid receptors, the gene encoding opioid receptors, and the signal transduction pathways triggered by opioids have been investigated extensively on neuronal cells in the last fourth decades. Chronic morphine is associated with differential gene expression in several brain structures (Ammon et al., 2003; Beitner-Johnson et al., 1992; Marie-Claire et al., 2004; McClung et al., 2005). Although some of the modifications observed in rodent models of addiction could be found postmortem in the brain of opiate addicts (Ferrer-Alcon et al., 2000, 2004; Albertson et al., 2006), it is difficult to extrapolate all the results obtained from the animal brain to the patients.

Interestingly, in the case of several psychological and neurologic troubles including bipolar disorder, schizophrenia and Parkinson disease, a correlation in gene expression modulation between blood cells and brain has been recently demonstrated (Bowden et al., 2006; Du et al., 2006). These results suggest that studies of the transcription level of certain genes in blood cells may give insights into their modulation in the brain. Moreover, in the case of major depressive disorder studies of gene expression modulations showed that peripheral leucocytes exhibit unique changes in the mRNA levels of several genes that are receptive to antidepressant treatment (Iga et al 2008). Therefore, study of gene expression in peripheral blood mononuclear cells (PBMC) may be useful for a better understanding of brain and neurological disease related pathways, and monitoring of therapeutic responses.

On immune cells, opioid receptors with similar pharmacological and biochemical characteristics to neuronal cells have been reported ( Bidlack, 2000; Gaveriaux et al., 1995; McCarthy et al., 2001; Sharp et al., 1998; Sharp, 2006; Suzuki et al., 2001a; Suzuki et al., 2001b; Suzuki et al., 2000; Wick et al., 1996). Moreover, morphine has been shown to interfere with lymphocytic cells functions following binding to these receptors (Rahim et al., 2002; Roy et al., 2004). Chronic morphine treatment has been shown to alter a number of immune parameters including phagocytosis (Eisenstein and Hilburger, 1998), antibody response in mice (Rahim et al., 2002) and cytokine production in human and mice peripheral blood mononuclear cells (PBMCs) (Pacifici et al., 2000; Peterson et al., 1989). Moreover, 
morphine withdrawal has been shown to alter immune response in mice (Belcheva et al., 2002; Hilburger et al., 1997). Gaveriaux-Ruff et al showed morphine immunosuppressive effects during an escalating dose protocol in mice and these effects were abolished in mu-receptor knockout animals (Gaveriaux-Ruff et al., 1998).

In order to facilitate the interplay between morphine-treated rat models and opiate-dependent patients we chose to work on an easily accessible tissue: PBMCs. To evaluate whether transcriptional profiling of PBMC could serve to identify genes regulated by morphine rats were chronically treated with morphine during five days, and the behavioral signs of spontaneous withdrawal were observed at different times after the last injection to select the time point at which the animals displayed the minimum withdrawal signs for subsequent analyses. High-density oligonucleotide arrays were used to assess global differential gene expression in the PBMCs. The changes in gene expression were also investigated for several transcripts by quantitative PCR $12 \mathrm{~h}$ and $36 \mathrm{~h}$ after the last injection when spontaneous withdrawal signs were minimum and maximum respectively. The regulations of the selected genes were also studied $4 \mathrm{~h}$ before the last injection in order to estimate the influence of the withdrawal on the observed effects. The results showed that chronic morphine regulates gene expression in PBMCs and interestingly among these genes several have previously been found modulated by morphine treatment in rat brain.

\section{Materials and Methods}

\section{Animals and drugs}

Male Sprague-Dawley rats (Janvier, Le Genest-Saint-Isle, France) weighing 180-250 $\mathrm{g}$ at the beginning of the experiments were housed four per cage. Animals were maintained under standard laboratory conditions $\left(21 \pm 1{ }^{\circ} \mathrm{C}, 55-60 \%\right.$ relative humidity, $12 \mathrm{~h}$ light/dark cycle, food and water ad libitum) for 3 to 5 days before the beginning of the experiments. Care and treatments of animals conformed to the ethical standards and guidelines promulgated by the European Communities Council Directive (86/609/EEC). All efforts were made to minimize animal suffering and to use only the number of animals necessary to produce reliable scientific data. Morphine chlorhydrate (Francopia, France) was dissolved in saline $(0.9 \% \mathrm{NaCl})$. Morphine and saline solutions $(0.1 \mathrm{~mL}$ per $100 \mathrm{~g}$ of body weight $)$ were injected intraperitoneally.

\section{Animal Treatments}

Dependence was induced in rats by repeated intraperitoneal injections of morphine twice daily at 08.00 AM and 19.00 PM. Morphine doses were progressively increased from 10 to $40 \mathrm{mg} \mathrm{kg}^{-1}$ injection: first day $2 \times 10 \mathrm{mg} \mathrm{kg}^{-1}$, second day $2 \times 20 \mathrm{mg} \mathrm{kg}^{-1}$, third day $2 \times 30 \mathrm{mg}$ $\mathrm{kg}^{-1}$, fourth and fifth days $2 \times 40 \mathrm{mg} \mathrm{kg}^{-1}$. Control group was treated with saline following the same procedure.

\section{Behavioral studies}

Spontaneous withdrawal syndromes were observed for $15 \mathrm{~min}$ in circular plexiglass observation boxes ( $30 \mathrm{~cm}$ wide; $40 \mathrm{~cm} \mathrm{high)} 12 \mathrm{~h}$, $18 \mathrm{~h}$ and $36 \mathrm{~h}$ after the last morphine injection. Two classes of withdrawal signs were measured: counted signs and observed signs. The number of bouts of teeth chattering, wet dog shakes, mastication and tremor were counted and the sum is a score for each counted signs. Ptosis, defecation, abnormal posture were observed over periods of $3 \mathrm{~min}$, with one point being given for the presence of each sign during each period. The number of periods showing the sign was then counted (maximum score 5). Global withdrawal score was calculated as the sum of scores for all signs. Body weight was measured during the treatment and before observation period.

\section{PBMC isolation and RNA extraction}

PBMC isolation was carried out at 3 time-points: $4 \mathrm{~h}$ before the last injection, $12 \mathrm{~h}$ and $36 \mathrm{~h}$ after the last injection on three independent animal groups. Animals were anaesthetized using pentobarbital $\left(100 \mathrm{mg} \mathrm{kg}^{-1}\right)$ at the mentioned time points and blood was collected by intracardiac ponction (8-10 mL per animal). Rat PBMCs were isolated from whole blood by density gradient centrifugation on Ficoll-Paque Plus ${ }^{\circledR}$ lymphocyte separation medium (GE Healthcare Life Science, France). The layer with PBMCs was removed and washed twice with saline $0.9 \%$ and the recovered cells were used directly for total RNA extraction. Total RNA was isolated with Rneasy Micro Kits (Qiagen, Courtaboeuf, France), following the manufacturer's protocol. Each RNA sample was prepared from PBMCs individually isolated from one animal whole blood. Quantification of total RNA was assessed by spectrophotometry using a Nanodrop ${ }^{\circledR}$ instrument (Nyxor, France).

\section{Microarray target preparation and Affymetrix hybridization}

The quality of the RNA samples was determined by electrophoresis using RNA labs chips (Agilent ${ }^{\circledR}$ ). Synthesis of cDNA, synthesis and biotinylation of cRNA, fragmentation and hybridization were all performed according to the manufacturer's instructions (Affymetrix, Santa Clara, CA, USA) at the Affymetrix genopole facility (CHU Saint-Louis, Paris). Briefly, double-stranded cDNA was synthesized from total RNA samples using a Superscript Choice Kit with a T7-dt24 primer incorporing a T7 RNA polymerase promoter. Biotinylated cRNA was prepared by in vitro transcription using Enzo Bioarray High Yield RNA Transcript Labeling kit and then fragmented. The fragmented and biotin-labeled cRNA samples were hybridized on Affymetrix ${ }^{\circledR}$ Rat Genome RAE230_2.0 Genechips (containing 31,000 
probe sets) according to the manufacturer's instructions. Scanned images of the arrays were converted to numerical data by GCOS software (Affymetrix) and outputted to tab delimited text files containing Affymetrix ${ }^{\circledR}$ ProbeSet ID, signals, present or absent detection calls, and detection P-values for each feature on the array. Comparison analyses were conducted using Dchip software 3.1 (www.dchip.org ).

\section{Microarray analysis}

DNA-Chip analyzer (DChip) version 2006 (Li and Wong, 2001) was used to analyze Affymetrix data. A comparison between the five hybridizations with morphine treatment and the five controls generated a change of P-value. The average percentage of probe sets that were called as present was $60.7 \%$ among the different hybridizations except for one of the morphine array (53.5\%), this array was then excluded from the subsequent study. Multiple comparisons of four morphine-treated against five control chips were therefore performed. To identify potentially regulated transcripts we chose a cut-off of $50 \%$ fold change (treated vs.Control Assay Signal Ratio) and $p<0.05$. Results are displayed as mean of fold induction and/or reduction. The selected transcripts after the Dchip analysis were characterized using NetAffix ${ }^{\text {TM }}$ Analysis center (https://www.affymetrix.com) and FatiGO+ (http://www.fatigo.org) (Al-Shahrour et al., 2006; Al-Shahrour et al., 2005). We used online tools that are specifically designed to assist investigators to classify the functional roles of the identified differentially expressed genes. The FatiGO+ utilizes the Gene Ontology (GO) database provided by the GO consortium ( http://www.geneontology.org/) and other databases as KEGG pathway. We compared overexpressed or underexpressed gene lists with rat RAE 230.2 array list. Then a Fisher's exact test was used to check for significant over representation of GO terms in one of the sets. Multiple test correction to account for the multiple hypothesis tested (one for each GO term) was applied (FDR adjusted test).

\section{Reverse transcription and Real-Time PCR}

Independent batches of RNA were obtained from PBMCs of morphine and saline-treated rats. Total RNAs were reverse transcribed in a final volume of $20 \mu \mathrm{L}$ containing $1 \mathrm{X}$ RT-PCR buffer (Invitrogen ${ }^{\circledR}$, France), $500 \mu \mathrm{M}$ each deoxynucleotide triphosphate, $20 \mathrm{U}$ of RNasin RNase inhibitor (Promega, France), $10 \mathrm{mM}$ DTT, $100 \mathrm{U}$ of Superscript II RNase $\mathrm{H}^{-}$reverse transcriptase (Invitrogen, France), $1.5 \mu \mathrm{M}$ random hexamers (Amersham-Pharmacia ${ }^{\circledR}$, France), and $1 \mu \mathrm{g}$ of total RNA. Samples were incubated at $20^{\circ} \mathrm{C}$ for $10 \mathrm{~min}$ and $42^{\circ} \mathrm{C}$ for 30 min, and reverse transcriptase was inactivated by heating at $99^{\circ} \mathrm{C}$ for $5 \mathrm{~min}$. PCR primers were chosen with the assistance of Oligo 6.42 software (MedProbe, Norway). The primer nucleotide sequences used in this study are listed in Table I. Fluorescent PCR analysis was performed using a LightCycler ${ }^{\circledR}$ instrument (Roche Diagnostics, France). The cDNAs were diluted 40 -fold and $5 \mu \mathrm{L}$ were added to the PCR reaction mix to yield a total volume of $10 \mu \mathrm{L}$. The PCR reagents were obtained from the FastStart DNA Master SYBR Green I kit (Roche Diagnostics, France). The reaction buffer contained $4 \mathrm{mM} \mathrm{MgCl} 2$ and $0.5 \mu \mathrm{M}$ of each primer. Amplification protocols consisted of $35-40$ cycles of denaturation at $94^{\circ} \mathrm{C}(5 \mathrm{~s})$, annealing at $64^{\circ} \mathrm{C}(5 \mathrm{~s})$, and extension at $72^{\circ} \mathrm{C}(10 \mathrm{~s})$. cDNAs from a naive rat blood were used to generate an external standard curve for each gene. We also quantified transcripts of the gene coding for the Ribosomal Protein Large, P0 (Rplp0), a component of the 60S subunit of ribosomes, as the endogenous RNA control and normalized each sample on the basis of its RPLP0 content.

\section{Statistical analysis}

All series of data were analyzed with GraphPad Prism ${ }^{\circledR} 4.0$ software. For behavioral experiment, three independent experiments were performed, 15 morphine-treated rats and 15 control rats were compared at each time-point. Data were analyzed by two-way ANOVA with Bonferonni post-test. For body weight study three independent experiments were performed, 28 treated and placebo rats were compared at each time-point. Data were analyzed by two-way repeated measures ANOVA with Bonferonni post-test. For real-time quantitative RT-PCR results, three additional experiments at $-4 \mathrm{~h},+12 \mathrm{~h}$ and $+36 \mathrm{~h}$ were carried out and the RNAs from 12-14 morphine-treated rats and 10-12 control rats were compared. Data were analyzed using Student's test between groups at each time point. Differences with $\mathrm{p}<0.05$ between experimental groups at each point were considered statistically significant.

\section{Results}

\section{Behavioral experiment}

Physical dependence was induced in male Sprague-Dawley rats by repeated i.p injections of morphine twice daily and the withdrawal signs were monitored in order to determine the time points for the transcriptional studies. The weight gain was monitored every $12 \mathrm{~h}$ throughout morphine treatment and withdrawal, as shown on figure 1a. A significant increase of $18 \%$ was observed in control rats and the weight of rats treated with morphine increased by $13 \%$ during the five days of morphine treatment. This difference was not statistically significant. The weight of the control group continued to increase during 4 days after the last injection of saline; while morphine withdrawal induced a significant reduction on weight gain in rats treated with the alkaloid. A maximum difference was observed in body weights of control versus morphine-treated rats $36 \mathrm{~h}$ after the last injection $(\mathrm{p}<0.001)$ (Figure 1a). 
Morphine-withdrawn animals showed behavioral signs of opiate withdrawal, including wet dog shakes, teeth chattering, diarrhea, mastication, abnormal posture and ptosis. The calculated global withdrawal scores are presented in figure $1 \mathrm{~b}$. Withdrawal signs were observed at $12 \mathrm{~h}, 18 \mathrm{~h}$ and $36 \mathrm{~h}$ after the last injection and global withdrawal scores of morphine-treated animals were significant $(\mathrm{p}<0.001)$ at each time-point. Twelve hours after the last morphine injection, all the withdrawal signs were already present but the global withdrawal score was less important than those calculated at $18 \mathrm{~h}$ and $36 \mathrm{~h}$ after the last injection. The $12 \mathrm{~h}$ and $36 \mathrm{~h}$ time points displaying the minimum and maximum withdrawal scores were therefore selected for the subsequent studies.

\section{Regulation of gene expression in the PBMCs}

The Affymetrix GeneChip ${ }^{\circledR}$ Rat Genome RAE 2302.0 was used to identify genes differentially regulated in the PBMCs of rats at + $12 \mathrm{~h}$ after the last morphine injection. To obtain a set of differentially expressed genes and global gene expression profiling, we used a combinaison of $\mathrm{P}$-value $(\mathrm{P}<0.05)$ and fold change value $(>1.5$ or $<0.66)$. Comparison of chronic morphine with control condition revealed 812 (596 up-regulated and 215 down-regulated) differentially expressed (50\% fold or more) gene transcripts in PBMCs of treated rats. Of the 812 significantly modulated candidates, only 394 were annotated and represented 276 distinct genes, whereas the others (51.5\%) were transcripted loci with various levels of matches to known genes. A selective list of the genes modulated in this study is presented in Table II. We used NetAffix ${ }^{\mathrm{TM}}$ Analysis Center and FatiGO+ to identify the signalling pathways and genes families regulated by chronic morphine (Figure 2). The results revealed several genes families that have been previously described as modulated by chronic morphine in the brain. We found that $7 \%$ of the 276 annoted genes regulated belong to the G-protein coupled receptor protein signalling pathway, these include G-protein coupled receptors and G-protein coupled protein. Signal transduction pathways were also represented such as mitogen activated protein kinase pathway and cAMP pathway. Other regulated genes have a role in immunity and defense process interleukin 1 receptor, type I (Illr1), interferon beta 1 (Ifnb1), and a role in pro-apoptotic Tissue inhibitor of metalloproteinase 3 (Timp3), Bc12 modifying factor (Bmf), guanine nucleotide binding protein, alpha q (Gnaq), NCK-associated protein 1 (Nckap1), and anti-apoptotic pathways [Sphingosine kinase 1 (Sphk1), Chemokine (C-C motif) ligand 2 (Ccl2), Fibroblast growth factor 8 (Fgf8)]. Three 5-hydroxytryptamine receptors 6, 7 and 2a (Htr6, Htr7 and Htr2a), and calcium channels were also identified.

\section{Validation of differentially regulated genes by quantitative RT-PCR at $12 \mathrm{~h}$}

In order to validate the regulation of 24 selected genes we performed quantitative real-time RT-PCR on samples collected at the same time-point (12h) as for the array analysis (minimum withdrawal). We chose genes of the G protein pathway (Gprk5, Gng11), genes of the Mapk pathway (similar to mitogen-activated protein kinase kinase kinase kinase 5 isoform 2), mitogen-activated protein kinase 7 (Mapk7) and genes known to be modulated in the brain by morphine treatment (Adcy5, Adenosine kinase, Htr2a). Since morphine promotes cells apoptosis, we also chose to confirm the regulation of genes implicated in this process such as Bmf, Nckap1, Timp3, and also genes implicated in cell adhesion such as Integrin beta 1 (Itgb1) and integrin alpha 6 (Itga6). Out of the 18 tested genes 12 were validated by Q-RT-PCR (Table III). Furthermore, the fold-changes obtained were similar to those calculated in the array experiments (Table II and table III). We also tested 6 genes that belong to the tested families and almost fulfill the criteria detailed in the material and methods section: regulator of G-protein signalling 10 (Rgs10) (1.46), membrane interacting protein of Rgs16 (Mir16) (1.39), mitogen-activated protein kinase 8 interacting protein 3 (Mapk8ip3) (1,35), adaptor-related protein complex 1, sigma 1 subunit (Ap1s1) (1.36), calpain 2 (Capn2) (1.4), RAS, guanyl releasing protein 2 (Rasgrp2) (1.22). We found that the regulations of Rgs10, Mir16, Capn2, Rasgrp2, were verified by quantitative real-time RT-PCR at $12 \mathrm{~h}$ (Table III).

\section{Regulation of differentially regulated genes by quantitative RT-PCR at $36 \mathrm{~h}$}

In order to compare the expression levels at the minimum and maximum withdrawal scores in our model, we carried out an additional independent experiment at $36 \mathrm{~h}$ to analyze the differential expression levels between morphine-treated and control rats of 18 genes confirmed or not at $12 \mathrm{~h}$. Four groups of genes could be distinguished according to their pattern of regulation at $+12 \mathrm{~h}$ and $+36 \mathrm{~h}$. Four genes (Adcy5, Mir 16, Camk4, and Anxa3) were significantly up-regulated at 12h but significantly down-regulated at 36h. A group with Itga6 and Rasgrp2 showed a sustained up-regulation at 12h and 36h. A group with Adk, Nckap1, Gng11, Gprk5, Rgs10, Capn2, Fg12, Sod2, Timp3, Ap1s1, and Itgb1 showed a significant up-regulation at 12h but no modulation at 36h. And a fourth group composed of Mapk8ip3 and Htr2A was not significantly modulated at $12 \mathrm{~h}$ but significantly regulated at $36 \mathrm{~h}$.

\section{Regulation of the validated genes during chronic morphine treatment}

In order to know how the validated genes were being expressed before the onset of the withdrawal process, quantitative real time PCR was performed on PBMCs of rat sacrificed on day 5. For all the tested genes the regulations observed $4 \mathrm{~h}$ before the last morphine injection confirmed those obtained 12 hours after the last morphine injection (Table III). Furthermore, the fold changes observed at $-4 \mathrm{~h}$ were very similar to those obtained at $+12 \mathrm{~h}$. In addition no significant regulation was found at $-4 \mathrm{~h}$ for the 7 genes that were not modulated at $+12 \mathrm{H}$.

\section{Discussion}


The aim of this study was to identify differentially expressed genes in blood cells of morphine-dependent rats in spontaneous withdrawal situation. The large majority of studies carried out to date have used opioid receptor antagonist-precipitated withdrawal syndrome. However, this experimental approach greatly differs from the clinical setting where the opiate withdrawal syndrome occurs as a result of drug intake cessation. To better mimic these conditions, spontaneous withdrawal was evaluated. We observed classical signs used in behavioral studies and found low levels of withdrawal scores. Indeed spontaneous withdrawal induces milder behavioral modulation than the naloxone-precipitated one. As expected, the severity of opiate withdrawal varied as a function of the time interval between the last morphine administration and testing. In order to study the modifications in gene expressions in morphine-dependent rats and to minimize the transcriptional effects of withdrawal, the $+12 \mathrm{~h}$ time point was selected for microarray analysis. At this time point, withdrawal symptoms and loss of weight were at their minimum. At $36 \mathrm{~h}$, the withdrawal signs were maximum, and this time point was therefore selected for comparison with the $12 \mathrm{~h}$ results. An additional time point ( $4 \mathrm{~h}$ before the last injection) was chosen in order to assess the modulation of the selected candidate genes before the beginning of the withdrawal process.

Several studies have demonstrated characteristic blood genomic profiles for different brain disorders and neurologic diseases (Du et al. , 2006; Tang et al., 2005; Tang et al., 2004). A study of gene expression in PBMCs from schizophrenic patients suggested a correlation between the gene expression modulations patterns in PBMCs and the severity of the schizophrenic syndrome (Bowden et al., 2006). In the case of migraine suffering patients differential gene expression modulations were found in platelets as compared to control patients ( Hershey et al., 2004). Tang and coworkers also found a specific gene expression pattern in PBMCs from Tourette syndrome patients (Tang et al., 2005). Moreover in the case of depression the low level of expression of alpha2a adrenergic receptors observed in the platelets of depressive patients could be increase after a treatment with an antidepressive compound (Garcia-Sevilla et al., 2004). These results suggest a correlation between the gene expression regulations in the brain and the blood cells in these pathologies. The identification of an easily accessible tissue (blood) where modifications of gene expression following chronic morphine treatment could give insight to those occurring in the CNS would facilitate clinical research on the mechanisms of addiction in humans (Sullivan et al., 2006). In this study, we used PBMCs as a model to study blood expression profile following morphine treatment.

Our results describe the regulation of various genes and pathways in PBMCs of rats treated with morphine. 17 out the 24 tested genes were validated by quantitative real-time PCR at $+12 \mathrm{~h}$. Interestingly the modulations observed on the last day of the morphine treatment were similar to those obtained at the $+12 \mathrm{~h}$ time point of the spontaneous withdrawal but evolved as the withdrawal state worsens. Among the regulated pathways in PBMCs some have been previously identified in vitro in transcription studies. Stefano et al have showed a regulation of apoptosis and cell adhesion genes in human peripheral blood leukocytes after acute morphine treatment (Stefano et al., 2005). In addition morphine has been shown to modulate immune responses (Eisenstein and Hilburger, 1998).

Interestingly, among the genes found regulated in PBMCs several have been previously reported to be involved in responses to morphine in different brain regions. The two major transcription pathways (Mapk and G protein coupled receptor) reported to be regulated by morphine treatment in brain (Asensio et al., 2006; Fan et al., 2002; Traynor and Neubig, 2005) were also found regulated in PBMCs. Opioid receptor activations lead to physiological responses via coupling to inhibitory guanine nucleotide-binding regulatory protein (Gold et al., 2003), modulating several effectors, such as adenylyl cyclases, and voltage-gated $\mathrm{Ca}^{2+}$ channels. In the present study, modulations of genes belonging to two major components of the development of opiate addiction were found in the PBMCs: the G-protein coupled receptor signalling (Gprk5, gng11, Rgs 10, Mir 16) and the cAMP signalling (Adcy5) pathways. Adcy5 has been shown to play an important role for the development of morphine behavioral effects (Kim et al., 2006). Nestler et al have shown that decreased activation of ERK1/2 might be relevant in modulating long lasting forms of synaptic plasticity in opiate addiction (Nestler, 2001). In the present study we observed an increase in the expression of several mitogen-activated protein kinases (Mapk7, similar to Mapkkkk5). Mapk pathway has been shown to be activated in various regions of rat brain by opioid receptors coupled to G-proteins (Schulz et al., 2004).

Electrophysiological studies have suggested a functional relationship between the opioid and serotoninergic systems in the rat prefrontal cortex involving the $\mu$ and Htr2a receptors (Marek, 2003). Moreover, an implication of Htr2a receptors in the dopamine release, locomotor response and behavioural sensitization to morphine has been demonstrated (Auclair et al., 2004). The present results showing a regulation of the serotonin receptor $\mathrm{Htr} 2 \mathrm{a}$ by morphine treatment are consistent with these findings. Integrins are transmembrane receptors allowing the interactions of cells with the extracellular matrix (Uings and Farrow, 2000). They are involved in several cellular functions including the modulation of G-protein-coupled receptors signalling (Berg et al., 2007). In this study we found that morphine treatment upregulated two integrins genes (Itgb1 and Itga6) in rat PBMCs. Moreover, the severity of the withdrawal symptoms did not affect the expression of these two genes. Interestingly, Itgb1 has been recently shown to regulate opioid receptor signalling in sensory neurons (Berg et al., 2007).

In conclusion, our data show that chronic morphine treatment induces transcriptional modifications in PBMCs that evolve with the withdrawal state of the animals. This suggests that PBMC gene expression patterns could be indicative of the disease stage. For some of the modulated genes the PBMC regulations confirmed previously reported brain modulations. In order to better characterize the correlations suggested here, a study of the modulation of the differentially regulated genes obtained in PBMCs, in brain structures involved 
in addiction, is currently carried out. This approach could help to identify important diagnostic/prognostic markers as well as potential therapeutic targets and mechanistic pathways.

\section{Ackowledgements:}

This work was supported by the Consortium national de recherche en genomique (CNRG) and the Mission Interministerielle de Lutte contre la Drogue et la Toxicomanie (MILDT).

\section{References:}

List of references

- Al-Shahrour F, Minguez P, Tarraga J , Montaner D, Alloza E, Vaquerizas JM , Conde L, Blaschke C, Vera J , Dopazo J 2006; Babelomics: a systems biology perspective in the functional annotation of genome-scale experiments. Nucleic Acids Res. 34: W472- 476

- Al-Shahrour F, Minguez P, Vaquerizas JM , Conde L, Dopazo J 2005; BABELOMICS: a suite of web tools for functional annotation and analysis of groups of genes in high-throughput experiments. Nucleic Acids Res. 33: W460- 464

- Albertson DN , Schmidt CJ , Kapatos G, Bannon MJ 2006; Distinctive profiles of gene expression in the human nucleus accumbens associated with cocaine and heroin abuse. Neuropsychopharmacology. 31: 2304- 2312

- Ammon S , Mayer P, Riechert U, Tischmeyer H, Hollt V 2003; Microarray analysis of genes expressed in the frontal cortex of rats chronically treated with morphine and after naloxone precipitated withdrawal. Brain Res Mol Brain Res. 112: 113- 125

- Asensio VJ , Miralles A, Garcia-Sevilla JA 2006; Stimulation of mitogen-activated protein kinase kinases (MEK1/2) by mu-, delta- and kappa-opioid receptor agonists in the rat brain: regulation by chronic morphine and opioid withdrawal. Eur J Pharmacol. 539: 49- 56

- Auclair A, Drouin C, Cotecchia S, Glowinski J, Tassin JP 2004; 5-HT2A and alpha 1b-adrenergic receptors entirely mediate dopamine release, locomotor response and behavioural sensitization to opiates and psychostimulants. Eur J Neurosci. 20: 3073- 3084

- Beitner-Johnson D , Guitart X, Nestler EJ 1992; Neurofilament proteins and the mesolimbic dopamine system: common regulation by chronic morphine and chronic cocaine in the rat ventral tegmental area. J Neurosci. 12: 2165- 2176

- Belcheva MM , Haas PD , Tan Y, Heaton VM , Coscia CJ 2002; The fibroblast growth factor receptor is at the site of convergence between mu-opioid receptor and growth factor signaling pathways in rat C6 glioma cells. J Pharmacol Exp Ther. 303: 909- 918

- Berg KA , Zardeneta G , Hargreaves KM , Clarke WP, Milam SB 2007; Integrins regulate opioid receptor signaling in trigeminal ganglion neurons. Neuroscience. 144: 889897

- Bidlack JM 2000; Detection and function of opioid receptors on cells from the immune system. Clin Diagn Lab Immunol. 7: 719- 723

- Bowden NA, Weidenhofer J, Scott RJ , Schall U, Todd J , Michie PT , Tooney PA 2006; Preliminary investigation of gene expression profiles in peripheral blood lymphocytes in schizophrenia. Schizophr Res. 82: 175- 183

- Du X, Tang Y, Xu H , Lit L, Walker W , Ashwood P, Gregg JP , Sharp FR 2006; Genomic profiles for human peripheral blood T cells, B cells, natural killer cells, monocytes, and polymorphonuclear cells: comparisons to ischemic stroke, migraine, and Tourette syndrome. Genomics. 87: 693- 703

- Eisenstein TK , Hilburger ME 1998; Opioid modulation of immune responses: effects on phagocyte and lymphoid cell populations. J Neuroimmunol. 83: 36- 44

- Fan X, Zhang J, Zhang X, Yue W, Ma L 2002; Acute and chronic morphine treatments and morphine withdrawal differentially regulate GRK2 and GRK5 gene expression in rat brain. Neuropharmacology. 43: 809- 816

- Ferrer-Alcon M, Garcia-Sevilla JA , Jaquet PE, La Harpe R, Riederer BM , Walzer C, Guimon J 2000; Regulation of nonphosphorylated and phosphorylated forms of neurofilament proteins in the prefrontal cortex of human opioid addicts. J Neurosci Res. 61: 338- 349

- Ferrer-Alcon M , La Harpe R, Garcia-Sevilla JA 2004; Decreased immunodensities of [mu]-opioid receptors, receptor kinases GRK 2/6 and [beta]-arrestin-2 in postmortem brains of opiate addicts. Molecular Brain Research. 121: 114- 122

- Garcia-Sevilla JA, Ventayol P, Perez V, Rubovszky G, Puigdemont D, Ferrer-Alcon M, Andreoli A, Guimon J, Alvarez E 2004; Regulation of platelet alpha 2A-adrenoceptors, Gi proteins and receptor kinases in major depression: effects of mirtazapine treatment. Neuropsychopharmacology. 29: 580- 588

- Gaveriaux-Ruff C, Matthes HW , Peluso J, Kieffer BL 1998; Abolition of morphine-immunosuppression in mice lacking the mu-opioid receptor gene. Proc Natl Acad Sci U S A. 95: 6326- 6330

- Gaveriaux C, Peluso J, Simonin F, Laforet J, Kieffer B 1995; Identification of kappa- and delta-opioid receptor transcripts in immune cells. FEES Lett. $369: 272-276$

- Gold SJ , Han MH, Herman AE, Ni YG, Pudiak CM, Aghajanian GK, Liu RJ , Potts BW , Mumby SM , Nestler EJ 2003; Regulation of RGS proteins by chronic morphine in rat locus coeruleus. Eur J Neurosci. 17: 971- 980

- Hershey AD, Tang Y, Powers SW , Kabbouche MA, Gilbert DL, Glauser TA, Sharp FR 2004; Genomic abnormalities in patients with migraine and chronic migraine: preliminary blood gene expression suggests platelet abnormalities. Headache. 44: 994- 1004

- Hilburger ME , Adler MW , Rogers TJ , Eisenstein TK 1997; Morphine alters macrophage and lymphocyte populations in the spleen and peritoneal cavity. J Neuroimmunol. 80: $106-114$

- Kim KS , Lee KW , Lee KW , Im JY, Yoo JY , Kim SW , Lee JK , Nestler EJ , Han PL 2006; Adenylyl cyclase type 5 (ACS) is an essential mediator of morphine action. Proc Natl Acad Sci U S A. 103: 3908- 3913

- Li C, Wong WH 2001; Model-based analysis of oligonucleotide arrays: expression index computation and outlier detection. Proc Natl Acad Sci U S A. 98 : $31-36$

- Marek GJ 2003; Behavioral evidence for mu-opioid and 5-HT2A receptor interactions. Eur J Pharmacol. 474: 77- 83

- Marie-Claire C , Courtin C , Roques BP, Noble F 2004; Cytoskeletal genes regulation by chronic morphine treatment in rat striatum. Neuropsychopharmacology. 29: 22082215

- McCarthy L , Wetzel M, Sliker JK , Eisenstein TK , Rogers TJ 2001; Opioids, opioid receptors, and the immune response. Drug Alcohol Depend. 62: 111- 123

- McClung CA, Nestler EJ , Zachariou V 2005; Regulation of gene expression by chronic morphine and morphine withdrawal in the locus ceruleus and ventral tegmental area. J Neurosci. 25: 6005- 6015

- Nestler EJ 2001; Molecular basis of long-term plasticity underlying addiction. Nat Rev Neurosci. 2: 119- 128

- Pacifici R , di Carlo S , Bacosi A, Pichini S , Zuccaro P 2000; Pharmacokinetics and cytokine production in heroin and morphine-treated mice. Int J Immunopharmacol. 22: 603- 614

- Peterson PK , Gekker G, Brummitt C, Pentel P, Bullock M, Simpson M, Hitt J , Sharp B 1989; Suppression of human peripheral blood mononuclear cell function by methadone and morphine. J Infect Dis. 159: 480- 487

- Rahim RT, Adler MW, Meissler JJ Jr, Cowan A, Rogers TJ, Geller EB , Eisenstein TK 2002; Abrupt or precipitated withdrawal from morphine induces immunosuppression. J Neuroimmunol. 127: 88- 95

- Roy S, Wang J, Gupta S, Charboneau R, Loh HH, Barke RA 2004; Chronic morphine treatment differentiates T helper cells to Th2 effector cells by modulating transcription factors GATA 3 and T-bet. Journal of Neuroimmunology. 147: 78- 81

- Schulz R , Eisinger DA, Wehmeyer A 2004; Opioid control of MAP kinase cascade. European Journal of Pharmacology. 500: 487- 497

- Sharp BM 2006; Multiple opioid receptors on immune cells modulate intracellular signaling. Brain Behav Immun. 20: 9- 14

- Sharp BM , Roy S , Bidlack JM 1998; Evidence for opioid receptors on cells involved in host defense and the immune system. J Neuroimmunol. 83: 45- 56

- Stefano GB , Burrill JD , Labur S , Blake J , Cadet P 2005; Regulation of various genes in human leukocytes acutely exposed to morphine: expression microarray analysis. Med Sci Monit. 11: MS35- 42 
- Sullivan PF, Fan C, Perou CM 2006; Evaluating the comparability of gene expression in blood and brain. Am J Med Genet B Neuropsychiatr Genet. 141: 261- 268

- Suzuki S , Chuang LF , Doi RH , Bidlack JM , Chuang RY 2001a; Kappa-opioid receptors on lymphocytes of a human lymphocytic cell line: morphine-induced up-regulation as evidenced by competitive RT-PCR and indirect immunofluorescence. Int Immunopharmacology. 1: 1733- 1742

- Suzuki S , Chuang TK , Chuang LF , Doi RH , Chuang RY 2001b; Morphine upregulates kappa-opioid receptors of human lymphocytes. Adv Exp Med Biol. 493: 81- 87

- Suzuki S , Miyagi T , Chuang TK, Chuang LF , Doi RH, Chuang RY 2000; Morphine upregulates mu opioid receptors of human and monkey lymphocytes. Biochem Biophys Res Commun. 279: 621- 628

- Tang Y, Gilbert DL, Glauser TA , Hershey AD , Sharp FR 2005; Blood gene expression profiling of neurologic diseases: a pilot microarray study. Arch Neurol. 62: 210- 215

- Tang Y, Schapiro MB , Franz DN, Patterson BJ , Mickey FJ , Schorry EK, Hopkin RJ , Wylie M , Narayan T , Glauser TA , Gilbert DL, Hershey AD , Sharp FR 2004;

Blood expression profiles for tuberous sclerosis complex 2, neurofibromatosis type 1, and Down's syndrome. Ann Neurol. 56: 808- 814

- Traynor JR , Neubig RR 2005; Regulators of G prtein signaling and drugs of abuse. Mol Interv. 5: 30- 41

- Uings IJ , Farrow SN 2000; Cell receptors and cell signalling. J Clin Pathol. 53: 295- 299

- Wick MJ , Minnerath SR, Roy S, Ramakrishnan S, Loh HH 1996; Differential expression of opioid receptor genes in human lymphoid cell lines and peripheral blood lymphocytes. J Neuroimmunol. 64: 29- 36

\section{Figure 1}

a) Evolution of weight variation as compared to weight before the first injection, $n=15$ rats per treatment. Body weight of each rat was measured before the injection (twice daily from 5 days) or the observation (from $+12 \mathrm{~h}$ to $96 \mathrm{~h}$ after the last injection). Three independent experiments were achieved. Results are expressed as mean \pm .SEM. ${ }^{*} \mathrm{p}<0.05$, ${ }^{* *} \mathrm{p}<0.01$, ${ }^{* * *} \mathrm{p}<0.001$, NS: non significant Two-way repeated measure ANOVA. b) Evolution of global withdrawal score. Mean \pm SEM of opiate withdrawal score $(n=15$ rats per treatment $)$ at $+12 \mathrm{~h},+18 \mathrm{~h}$ and $+36 \mathrm{~h}$ after the last injection. Two Way ANOVA ${ }^{*} \mathrm{p}<0.05 ;{ }^{* *} \mathrm{p}<0.01 ;{ }^{* * *} \mathrm{p}<0.001$.

a

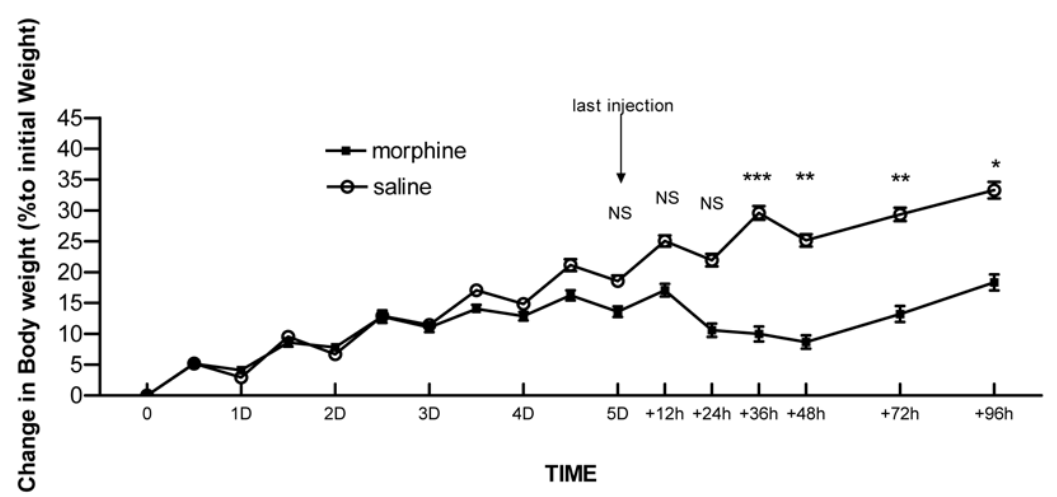

b

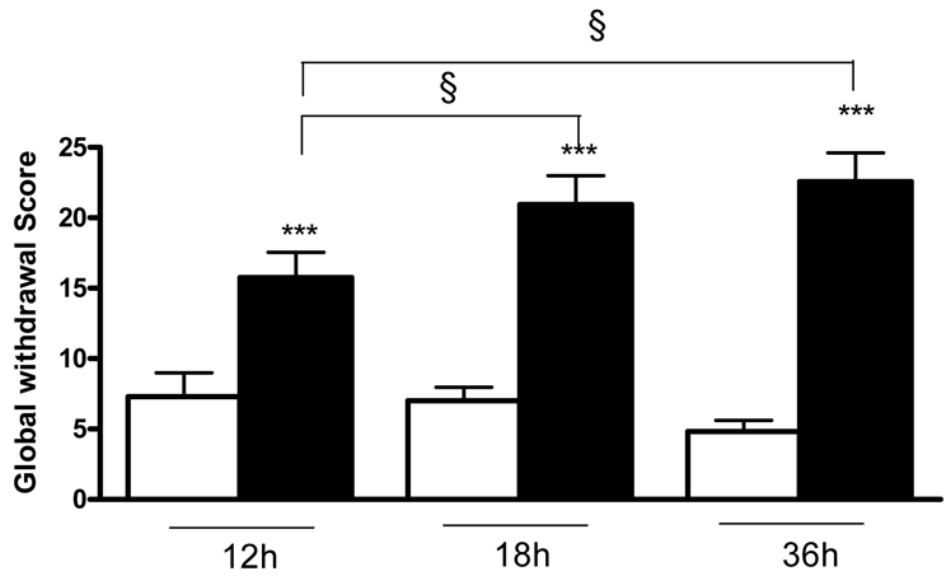

morphine

saline 
Figure 2

812 gene transcripts were identified, 596 up-regulated and 215 down-regulated genes under morphine treatment. Only 276 were identified as distinct gene. Data were presented according to Gene ontology classification of the biological processes most frequently involved by the 276 genes. The percentage distribution of up- and down-regulated genes with GO annotation in each category of biological process was shown. Each asterisk $\left(^{*}\right)$ represent a significant differential regulation in the category compared $(\mathrm{p}<0.05$ by Fisher).

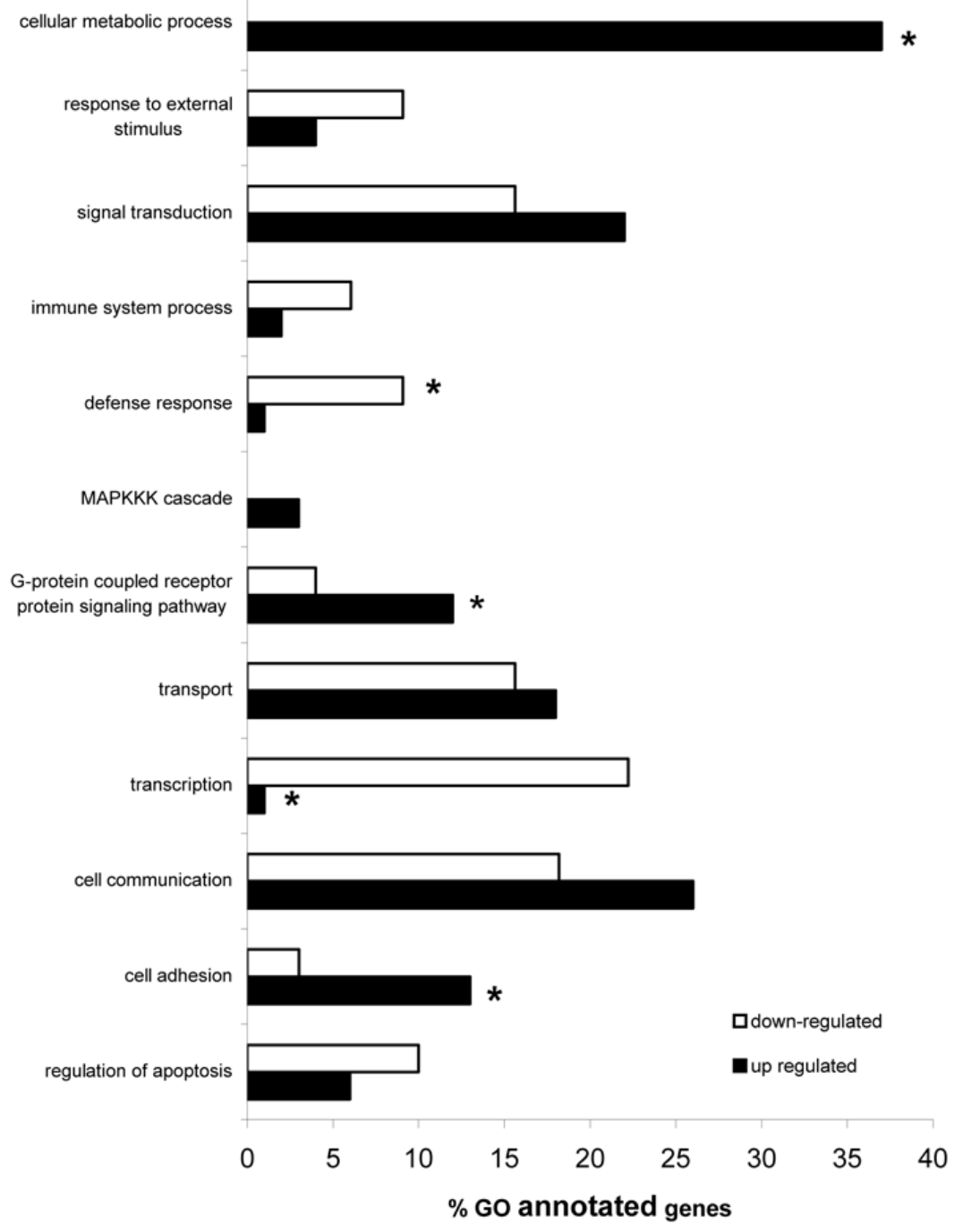


Table I

Primer sequences used for SYBR Green-based real-time quantitative polymerase chain reaction.

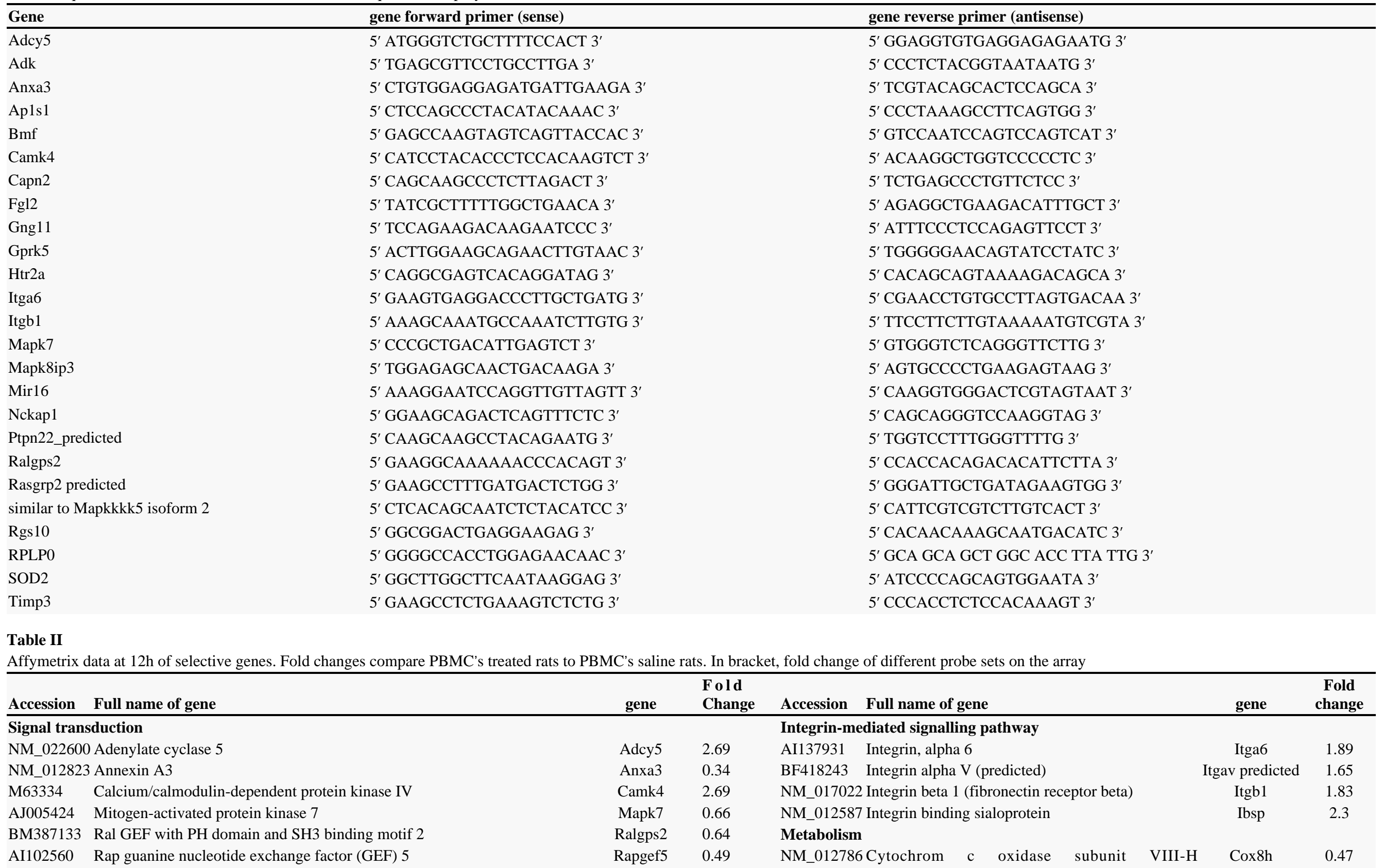


BI279720 RAS-like, family 12 (predicted)

AI577569 RAS protein-specific guanine nucleotide-releasing factor 1

AA945062 Rho GTPase activating protein 8

BF396580 Rho GTPase activating protein 5 similar to mitogen-activated

BI291366 protein kinase kinase kinase kinase 5 isoform 2 (predicted)

G-protein coupled receptor protein signaling pathway

NM_017254 5-hydroxytryptamine (serotonin) receptor 2A

L03202 5-hydroxytryptamine (serotonin) receptor 6

X69663 5-hydroxytryptamine (serotonin) receptor 7

BG379920 Adenosine A3 receptor

NM 012768 Dopamine receptor D5

AI012890 G protein-coupled receptor 43

BF404188 G protein-coupled receptor 137B (predicted)

NM_030829 G protein-coupled receptor kinase 5

NM_022396 Guanine nucleotide binding protein (G protein), gamma 11

NM 031034 Guanine nucleotide binding protein, alpha 12

BE117491 Guanine nucleotide binding protein, alpha q polypeptide

BI293698 HtrA serine peptidase 3 (predicted)

NM_022800 purinergic receptor P2Y, G-protein coupled 12

\section{Transport}

NM_031760 ATP-binding cassette, sub-family B (MDR/TAP), member 11

NM_080582 ATP-binding cassette, sub-family B (MDR/TAP), member 6

Apoptosis

NM_139258 Bcl2 modifying factor

NM 019127 interferon beta 1, fibroblast

BM383722 NCK-associated protein 1

AI009159 Tissue inhibitor of metalloproteinase 3 (Sorsby fundus dystrophy, pseudoinflammatory)

\section{Calcium ion transport}

AF361341 Calcium channel, voltage-dependent, gamma subunit 4

AF394940 Calcium channel, voltage-dependent, $L$ type, alpha 1C subunit

AF290212 Calcium channel, voltage-dependent, T type, alpha 1G subunit

NM 031601 Calcium channel, voltage-dependent, T type, alpha $1 \mathrm{H}$ subunit

Cell adhesion

NM_022184 Calcium/calmodulin-dependent serine protein kinase (MAGUK family)

AF065147 CD44 antigen

AI227627 CD9 antigen
Rasgrf1 $\quad 3.97$

Arhgap8 $\quad 0.38$

Arhgap5 Similar 0.39

Mapkkkk5 2.23

isoform 2

Htr2a $\quad 1.74$

Htr6 $\quad 0.64$

Htr7 $\quad 1.67$

Eaf2/Adora3 1.6

Drd5 $\quad 1.8$

Gpr43 $\quad 2.5$

Gpr137b $\quad 2.01$

Gprk5 $\quad 2.08$

Gng11 $\quad 1.57$

Gna12 $\quad 1.67$

Gnaq $\quad 1.54$

Htra3 predicted 0.56

P2ry12 2.77

Abcb11 $\quad 1.54$

Abcb6 $\quad 1.77$

Bmf $\quad 1.93$

Ifnb1 $\quad 0.51$

Nckap1 $\quad 2.55$

Timp3 2.93

Cacng4 $\quad 1.62$

Cacna1c $\quad 0.66$

Cacnalg 2.3

Cacnalh $\quad 1.83$

Cask $\quad 0.58$

$\mathrm{Cd} 44 \quad 1.54$

Cd9 1.6 (heart/muscle)

M58041 Cytochrome P450, family 2, subfamily c, Cyp2c70 polypeptide 70

NM 031509 Glutathione S-transferase A3

Gsta3

Gstt2

NM_012796 Glutathione S-transferase, theta 2

2.57

U48220 Cytochrome P450, family 2, subfamily d, Cyp2d22 polypeptide 22

\section{Cell differenciation}

NM 019242 Interferon-related developmental regulator $1 \quad$ Ifrd1

NM_012731 Neurotrophic tyrosine kinase, receptor, type 2 $\quad$ Ntrk2 1.62

AB049572 sphingosine kinase $1 \quad$ Sphk1

Inflammatory

NM_013123 Interleukin 1 receptor, type 1

II1r1

1.73

Transcription

BE096021 Jun D proto-oncogene

Jund

BG666291 Kruppel-like factor 7 (ubiquitous) (predicted)

Klf7 predicted

Immune response

BF403233 RT1 class Ib, locus M3

RT1-M3 2.31

RT292055 class Ib, locus Aw2

RT1-Aw2

$\mathrm{Ccl} 2$

\section{Others functions}

BI298352 Adaptor-related protein complex 3, beta 2 subunit Ap3b2 (predicted)

U90340 Adenosine kinase

NM_017135 Adenylate kinase 3-like 1

NM_031518 Cd200 antigen

BF565278 DnaJ (Hsp40) homolog, subfamily A, member 4

BF404861 DnaJ (HSP40) homolog, subfamily C, member 14

AF323608 Fibrinogen-like 2

NM_133286 fibroblast growth factor 8

BE107694 G protein-coupled receptor kinase-interactor2

BF404562 Gamma-aminobutyric acid A receptor, gamma 2

AF090113 Glutamate receptor interacting protein 2

BM391206 Histone 1, H2bh

X00336 Interferon-alpha 1

NM_012983 Myosin ID

AI045505 Myosin X (predicted)

predicted

Adk

Ak311

Cd200

Dnaja4

Dnajc14

Fgl2

Fgf8

Git2

Gabrg2

Grip2

Hist1h2bh

Ifna1

Myold

Myo10

predicted

NM_012604 myosin, heavy polypeptide 3, skeletal muscle, Myh3 embryonic

NM_013194 myosin, heavy polypeptide 9, non-muscle

Myh9

AA963282 Nicotinamide nucleotide adenylyltransferase 3

Nmnat3 


\section{Table III}

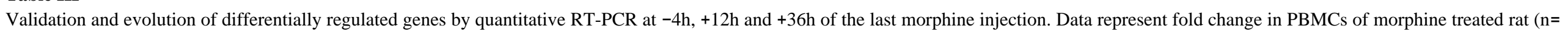

12-14) as compared to saline treated rats $(\mathrm{n}=10-12)$.

\begin{tabular}{|c|c|c|c|c|c|c|}
\hline \multirow{2}{*}{$\frac{\text { Gene }}{\text { Adcy5 }}$} & \multicolumn{2}{|c|}{$-4 H$} & \multicolumn{2}{|c|}{$+12 \mathrm{H}$} & \multicolumn{2}{|c|}{$+36 \mathrm{H}$} \\
\hline & $1.93^{* * *}$ & r & $2^{*}$ & x & $0.39^{* *}$ & 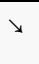 \\
\hline Anxa3 & nd & & $1.88^{*}$ & $\pi$ & $0.5^{* *}$ & $\searrow$ \\
\hline Camk4 & $1.24^{*}$ & $\pi$ & $1.38^{*}$ & x & $0.75^{*}$ & 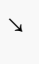 \\
\hline Mir16 & $1.37^{\star *}$ & r & $1.39^{\star \star \star}$ & $\pi$ & $0.74^{*}$ & 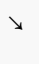 \\
\hline Rasgrp2 & $1.16^{*}$ & ${ }^{x}$ & $1.22^{*}$ & x & $1.27^{*}$ & $\pi$ \\
\hline Itga6 & $1.84^{* \star *}$ & r & $1.6^{* *}$ & r & $1.81^{*}$ & $\pi$ \\
\hline Adk & $1.58^{* *}$ & त & $1.67^{\star *}$ & $\pi$ & 1.1 & - \\
\hline Capn2 & $1.52^{\star *}$ & त & $1.4^{*}$ & $\pi$ & 0.98 & - \\
\hline Fgl2 & $1.95^{\star *}$ & 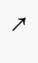 & $1.6^{*}$ & $\pi$ & 1.01 & - \\
\hline Gng11 & $2.22^{*}$ & $\pi$ & $2.17^{* *}$ & $\pi$ & 0.98 & - \\
\hline Gprk5 & $2.43^{* * *}$ & r & $1.56^{*}$ & $x$ & 1.01 & - \\
\hline Itgb1 & $1.69^{* *}$ & $\pi$ & $1.59^{\star *}$ & त & 0.98 & - \\
\hline Nckap1 & $2.57^{*}$ & r & $1.69^{*}$ & $\pi$ & 0.98 & - \\
\hline Rgs 10 & $1.5^{* \star}$ & त & $1.46^{* *}$ & $\pi$ & 0.97 & - \\
\hline Sod2 & $2^{* *}$ & r & $2.44^{* *}$ & $\pi$ & 1.02 & - \\
\hline Timp3 & $2.97^{\star *}$ & r & $2.14^{\star *}$ & त & 1.09 & - \\
\hline Ap1s1 & $1.18^{*}$ & r & $1.36^{*}$ & r & 0.97 & - \\
\hline mapk8ip3 & 1.21 & - & 1.18 & - & $0.64^{*}$ & $y$ \\
\hline $\mathrm{Htr} 2 \mathrm{a}$ & nd & & 1.38 & - & $0.46^{* *}$ & 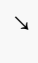 \\
\hline Ralgps2 & 1.02 & - & 1.22 & - & 0.29 & - \\
\hline $\mathrm{Bmf}$ & 0.83 & - & 0.19 & - & nd & \\
\hline Mapk7 & 1.13 & - & 0.38 & - & nd & \\
\hline Ptpn22 predicted & 1.08 & - & 1 & - & nd & \\
\hline similar to Mapkkkk5 isoform 2 & 0.97 & - & 0.63 & - & nd & \\
\hline
\end{tabular}


${ }^{* *} \mathrm{p}<0.01$

$\mathrm{p}<0.001$ as compared to control group. 